Article

\title{
Localization of Viral Epitope-Specific CD8 T Cells during Cytomegalovirus Latency in the Lungs and Recruitment to Lung Parenchyma by Airway Challenge Infection
}

\author{
Franziska Blaum ${ }^{1}$, Dominika Lukas ${ }^{2}{ }^{\circledR}$, Matthias J. Reddehase ${ }^{1, *}$ and Niels A. W. Lemmermann ${ }^{1}(\mathbb{D}$ \\ 1 Institute for Virology, Research Center for Immunotherapy (FZI), University Medical Center of the Johannes \\ Gutenberg-University Mainz, 55131 Mainz, Germany; frablaum@uni-mainz.de (F.B.); \\ lemmermann@uni-mainz.de (N.A.W.L.) \\ 2 Department of Dermatology, University of Cologne, University Hospital Cologne and Faculty of Medicine, \\ 50937 Cologne, Germany; dominika.lukas@uk-koeln.de \\ * Correspondence: matthias.reddehase@uni-mainz.de
}

Citation: Blaum, F.; Lukas, D.; Reddehase, M.J.; Lemmermann, N.A.W. Localization of Viral Epitope-Specific CD8 T Cells during Cytomegalovirus Latency in the Lungs and Recruitment to Lung Parenchyma by Airway Challenge Infection. Life 2021, 11, 918. https:/ / doi.org/10.3390/life11090918

Academic Editors: Pero Lučin, Hana Mahmutefendić Lučin and Gordana Blagojević Zagorac

Received: 13 August 2021

Accepted: 2 September 2021

Published: 4 September 2021

Publisher's Note: MDPI stays neutral with regard to jurisdictional claims in published maps and institutional affiliations.

Copyright: (c) 2021 by the authors. Licensee MDPI, Basel, Switzerland. This article is an open access article distributed under the terms and conditions of the Creative Commons Attribution (CC BY) license (https:/ / creativecommons.org/licenses/by/ $4.0 /)$.

\begin{abstract}
Interstitial pneumonia is a life-threatening clinical manifestation of cytomegalovirus infection in recipients of hematopoietic cell transplantation (HCT). The mouse model of experimental HCT and infection with murine cytomegalovirus revealed that reconstitution of virus-specific $\mathrm{CD} 8^{+} \mathrm{T}$ cells is critical for resolving productive lung infection. $\mathrm{CD}^{+} \mathrm{T}$-cell infiltrates persisted in the lungs after the establishment of latent infection. A subset defined by the phenotype $\mathrm{KLRG}^{+} \mathrm{CD}^{2} 2 \mathrm{~L}^{-}$expanded over time, a phenomenon known as memory inflation (MI). Here we studied the localization of these inflationary T effector-memory cells (iTEM) by comparing their frequencies in the intravascular and transmigration compartments, the IVC and TMC, respectively, with their frequency in the extravascular compartment (EVC), the alveolar epithelium. Frequencies of viral epitope-specific iTEM were comparable in the IVC and TMC but were reduced in the EVC, corresponding to an increase in $\mathrm{KLRG}^{-}{ }^{-} \mathrm{CD} 62 \mathrm{~L}^{-}$conventional T effector-memory cells (cTEM) and a decrease in functional IFN $\gamma^{+} \mathrm{CD}^{+} \mathrm{T}$ cells. As maintained expression of KLRG1 requires stimulation by antigen, we conclude that iTEM lose KLRG1 and convert to CTEM after transmigration into the EVC because pneumocytes are not latently infected and, therefore, do not express antigens. Accordingly, antigen re-expression upon airway challenge infection recruited virus-specific $\mathrm{CD} 8^{+} \mathrm{T}$ cells to TMC and EVC.
\end{abstract}

Keywords: antigen presentation; CD8 T cells; cytomegalovirus (CMV); effector-memory T cells (TEM); hematopoietic cell transplantation (HCT); interstitial pneumonia; latent infection; lungs; lung parenchyma; memory inflation (MI)

\section{Introduction}

Human cytomegalovirus (hCMV) is a prototype member of the $\beta$-subfamily of the herpes virus family [1]. Whereas primary infection passes mostly undiagnosed without overt clinical symptoms or organ disease when held in check by an intact innate and adaptive immune system in the otherwise healthy, immunocompetent host, unrestricted cytopathogenic tissue infection can lead to multiple-organ failure with often lethal outcome in an immunocompromised host [2-4].

A significant public health and economic impact $[5,6]$, and the main argument for the development of a CMV vaccine [7-10], results from birth defects caused by hCMV in an immunologically immature embryo/fetus after congenital infection following diaplacental transmission of the virus [11,12] after primary or recurrent infection during pregnancy [13].

After clearance of productive CMV infection, a latent infection, briefly referred to as "latency", is established, which is defined by the presence of replication-competent viral genomes that are silenced at loci critical for completion of the viral replicative cycle so that infectious progeny is not produced [14,15]. However, there is increasing evidence for viral 
gene expression during latency that does not follow the canonical temporal cascade of gene expression during productive infection [16] and that can impact the cellular secretome to create a latency-modulated microenvironment [17-20].

Patients at risk of CMV disease following productive reactivation of latent virus are recipients of solid-organ transplantation (SOT), who become immunosuppressed to prevent graft rejection, as well as recipients of hematopoietic cell transplantation (HCT) transiently immunocompromised by hematoablative therapy of aggressive hematopoietic malignancies that are refractory to standard antitumoral therapies. On top of this, in the case of allogeneic HCT with family or unrelated donors differing in major (HLA) and/or minor histocompatibility antigens (mHAg), additional immunosuppressive therapy is applied to prevent graft-versus-host $(\mathrm{GvH})$ disease (for clinical overviews, see [21,22]).

In HCT with either donor or recipient or both being latently infected, hCMV can reactivate from latently infected donor cells of the myeloid hematopoietic lineage [23-28], as well as from latently infected cells present in the transplant recipient, presumably including a tissue cell type that is refractory to hematoablative antitumor therapy. Endothelial cells (EC) have been discussed as candidates [29]. Despite routine follow-up of HCT recipients by quantitative PCR to detect virus reactivation at the earliest possible occasion to initiate pre-emptive therapy with antiviral drugs, HCT-associated CMV disease remains a clinical problem due to virus variants that have developed drug resistance [30]. In such patients, immunotherapy by adoptive transfer of virus-specific $\mathrm{CD} 8^{+} \mathrm{T}$ cells has become the last resort to prevent CMV disease [31-34]. CMV infection of the lungs is the focus of our own work because interstitial CMV pneumonia represents the clinically most feared manifestation of hCMV infection in HCT patients, with an often lethal outcome if treatment fails [35-37].

The mouse model of experimental syngeneic, as well as allogeneic, HCT and infection with murine cytomegalovirus (mCMV) has contributed much to the understanding of fundamental common principles of CMV pathogenesis, immune evasion, and immune control, including the intervention by CD8 ${ }^{+}$T-cell-based immunotherapy (reviewed in [38-40]). Specifically, as first shown in the model of syngeneic HCT, efficient and timely reconstitution of virus-specific $\mathrm{CD} 8^{+} \mathrm{T}$ cells is crucial for preventing lethal viral pneumonia after acute primary infection [41]. Lung-infiltrating protective $\mathrm{CD} 8^{+} \mathrm{T}$ cells persist in the lungs after clearance of productive infection and the establishment of a latent infection [41]. The observation of an expansion of $\mathrm{CD} 8^{+} \mathrm{T}$ effector-memory cells (TEM) specific for certain viral epitopes in these persisting lung infiltrates [42] initiated extensive research on this phenomenon that is now known as memory inflation (MI) (for reviews, see [43-48]). The expanding cells represent a subset of $\mathrm{CD} 8^{+} \mathrm{T}$ cells that is characterized by the cell surface marker phenotype $\mathrm{KLRG1}^{+} \mathrm{CD} 62 \mathrm{~L}^{-}$[49], for which we have proposed the acronym iTEM for "inflationary T effector-memory cells" to distinguish them from the conventional $\mathrm{KLRG1}^{-} \mathrm{CD} 2 \mathrm{~L}^{-} \mathrm{T}$ effector-memory cells, the cTEM [50]. The iTEM differ from effector cells of the acute immune response by a prolonged life span due to IL15-mediated expression of the antiapoptotic protein Bcl-2 [51]. Importantly, MI represented by an expansion of the iTEM pool depends on a high load of latent viral genomes, which is achieved by systemic infection but not usually by local infection, after which viral replication and spread are limited by immune control in the draining regional lymph node ([50] and references therein).

Since its first description, the maintained expression of KLRG1, and thus the iTEM phenotype, is known to depend on continuous or at least frequent restimulation by antigen [52]. We have recently identified transient and stochastic expression of epitope-encoding viral genes during latency, and thus a sporadic presentation of viral antigenic peptides, as the viral molecular driver of MI $[53,54]$. This finding explained the independently described stochastic nature of expansion and contraction of viral epitope-specific CD8 ${ }^{+} \mathrm{T}$-cell clones during MI [55] and is in perfect accordance with a mathematical model of MI curve fitting, proposing frequent stimulation by antigen to smoothen episodes of pool expansions and contractions [56]. 
An open question concerns the precise microanatomical site(s) where latently infected cells present antigens for the restimulation of iTEM. Competing though, in our view, not mutually exclusive hypotheses proposed antigen presentation during viral latency to occur in lymphoid tissue [57] or at latently infected cells of the vasculature, for instance at endothelial cells (EC) in the capillaries of the vascular bed of the lungs [58]. In fact, we have previously shown that latent mCMV genomes in the lungs localize to CD $31^{+} \mathrm{CD} 146^{+}$ capillary wall EC [53].

Here we studied the localization of viral epitope-specific iTEM, cTEM, and T central memory cells (TCM) in latently infected lungs. We distinguished three compartments, namely (1) the intravascular compartment (IVC), (2) the transmigration compartment (TMC), which includes $\mathrm{CD}^{+} \mathrm{T}$ cells attached to capillary wall endothelium, cells in the process of extravasation, and cells that have arrived in the interstitium, as well as (3) the extravascular compartment (EVC) (Figure 1).

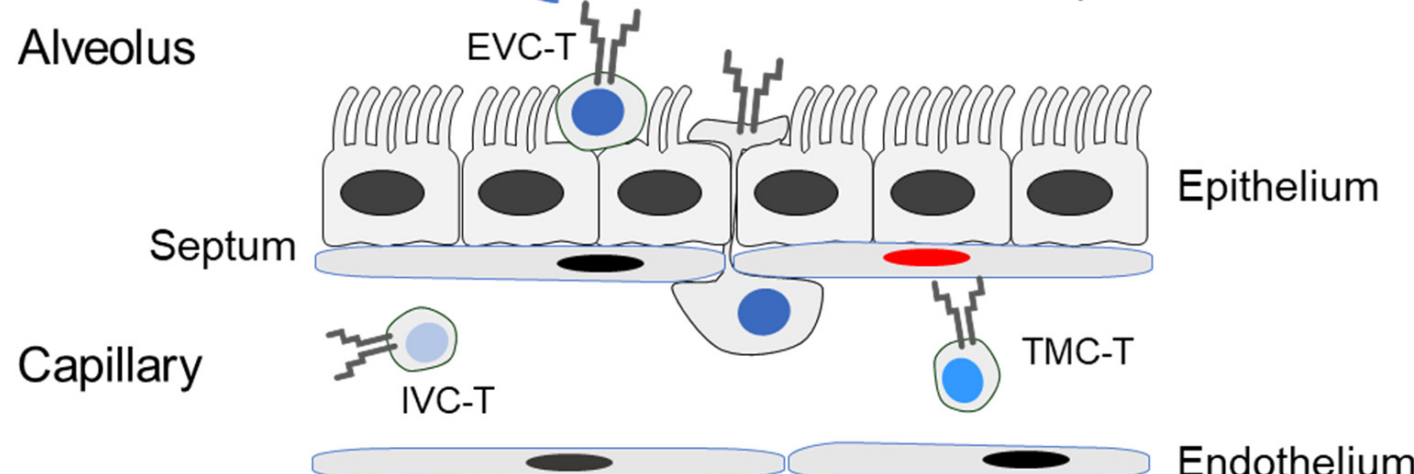

Figure 1. Scheme of the lung capillary-parenchyma interface. (IVC-T) T cell in the intravascular compartment, the capillary blood. (TMC-T) T cell in the transmigration compartment, comprising cells attached to the endothelium, cells in the process of transmigration, and cells in the interstitium. (EVC-T) T cell in the extravascular compartment loosely attached to the alveolar epithelium. (BAL) bronchoalveolar lavage. The red-stained nucleus symbolizes a latently infected endothelial cell.

Our data provide reasonable evidence to propose that iTEM receive their restimulation by latently infected cells outside of the lung parenchyma, and convert to cTEM by downregulation of KLRG1 when they localize to the lung parenchyma, which is not latently infected and, hence, does not present viral antigenic peptides for restimulation and maintained expression of KLRG1.

\section{Materials and Methods}

\subsection{Viruses and Mice}

Bacterial artificial chromosome (BAC)-cloned virus MW97.01, derived from BAC plasmid pSM3fr [59,60], is herein referred to as WT.BAC. For challenge infection, recombinant viruses mCMV-IE1-L176A+m164-I265A (referred to as $\triangle \mathrm{IDE}$ ) and mCMV-IE1-A176L+m164A265I (referred to as $\left.\triangle I D E \_r e v\right)$ [61] were used. Female BALBc/J mice (8 weeks old, haplotype $H-2^{d}$ ) were purchased from Harlan Laboratories and were housed under specified pathogen-free (SPF) conditions in the Translational Animal Research Center (TARC) of the University Medical Center of the Johannes Gutenberg-University Mainz.

\subsection{Establishment of Latent Infection after Experimental HCT}

Syngeneic hematopoietic cell transplantation (HCT) with 9-week-old female BALBc/J mice as bone marrow cell (BMC) donors and recipients was performed as described ([62] 
and references therein). In brief, hematoablative conditioning was performed by sublethal total-body $\gamma$-irradiation with a single dose of $6.5 \mathrm{~Gy}$. Donor BMC $\left(5 \times 10^{6} / \mathrm{mouse}\right)$ were infused into the tail vein of the recipients at $6 \mathrm{~h}$ after irradiation, followed by intraplantar infection with $10^{5}$ plaque-forming units (PFU) of WT.BAC injected into the left hind footpad. Latent infection was routinely confirmed by the presence of viral genomes in tissues in the absence of infectious virus [53].

\subsection{Airway Challenge Infection of Latently Infected Mice}

Mice latently infected with WT.BAC were superinfected with $1 \times 10^{6} \mathrm{PFU}$ of viruses $\triangle \mathrm{IDE}$ or $\triangle \mathrm{IDE} \_$rev by intratracheal virus application as described [63]. Four days later, localization of virus-specific $\mathrm{CD}^{+} \mathrm{T}$ cells to different lung compartments was quantified by cytofluorometric analysis.

\subsection{Preparation of Compartment-Specific Lung Cells}

Latently infected mice were lethally anesthetized by carbon dioxide inhalation. As the first step, bronchoalveolar lavage (BAL) leucocytes were isolated by flushing the airways with DPBS + 2\% FCS. [64]. Leucocytes from the bloodstream were isolated from blood taken by heart puncture directly after the BAL. Finally, leucocytes from lung tissue were isolated essentially as described ([50] and references therein). In brief, after perfusion of the lungs via the right ventricle to remove cells from the capillary bed of the lungs, the lungs were excised. Tracheae, bronchi, and pulmonary lymph nodes were discarded, and the lung lobes were minced. Lung tissue from 4 to 5 lungs was digested for $1 \mathrm{~h}$ at $37^{\circ} \mathrm{C}$ with constant stirring in $15 \mathrm{~mL}$ DMEM containing collagenase A (1.6 mg/mL; Roche, Mannheim, Germany) and DNase I (50 $\mu \mathrm{g} / \mathrm{mL}$, Sigma-Merck, Darmstadt, Germany). Mononuclear cells were enriched by density-gradient centrifugation for $30 \mathrm{~min}$ at $760 \times \mathrm{g}$ on lymphocyte separation medium Histopaque-1077 (Sigma-Merck).

\subsection{Cytofluorometric Analyses}

Single-cell suspensions were prepared from different lung compartments as described above. Unspecific staining was blocked with unconjugated anti-Fc $\gamma$ RII/III antibody (antiCD16/CD32; clone 2.4G2, BD Bioscience, Heidelberg, Germany). Living cells were detected using Fixable Viability Dye eFluor 780 (ThermoFisher Scientific, Langenselbold, Germany). Cells were specifically stained with the following antibodies for multi-color cytofluorometric analyses: BV421-conjugated anti-CD8 $\alpha$ (clone 53-6.7; BioLegend, San Diego, USA), FITC-conjugated anti-KLRG1 (clone 2F1; BioLegend), BV510-conjugated anti-CD45 (clone 30-F11; BioLegend), and PerCP-Cy5.5-conjugated anti-CD62L (clone MEL-14; Thermo Fisher Scientific). Phenotypic characterization of peptide-specific CD8 T cells was performed using PE-conjugated dextramers H-2Ld/YPHFMPTNL (IE1), and H-2Dd/AGPPRYSRI (m164) (Immudex, Copenhagen, Denmark). All cytofluorometric analyses were performed with flow cytometer BD FACSCanto and BD FACSDiva analysis software. For detailed analyses and documentation, FlowJo (version 10.6, BD Biosciences) was used.

\subsection{Quantitation of Functional Epitope-Specific CD8 ${ }^{+}$T Cells}

At the indicated time during viral latency established after HCT and infection, cells isolated from the different lung compartments served as responder cells in an IFN $\gamma$-based enzyme-linked immunospot (ELISpot) assay ([65] and references therein). Briefly, to detect functional, epitope-specific $\mathrm{CD}^{+} \mathrm{T}$ cells, synthetic peptides were exogenously loaded at a saturating concentration of $10^{-7} \mathrm{M}$ on P815 $\left(\mathrm{H}-2^{d}\right)$ mastocytoma cells for serving as stimulator cells in the assay. Graded numbers of leucocytes were seeded with the peptideloaded stimulator cells in triplicate microcultures. After $18 \mathrm{~h}$ of coculture, spots, each representing an IFN $\gamma$-secreting cell, were counted automatically, based on standardized criteria using ImmunoSpot S4 Pro Analyzer (Cellular Technology Limited, Cleveland, USA). 


\subsection{Antigenic Peptides}

Antigenic peptides reported to be presented by MHC class-I molecules $\mathrm{K}^{\mathrm{d}}$, $\mathrm{D}^{\mathrm{d}}$, and $\mathrm{L}^{\mathrm{d}}$ are derived from the mCMV open reading frames (ORF), M105, m123/IE1, m145, and m164 (listed with their amino acid sequences in [62]). Custom peptide synthesis with a purity of $>80 \%$ was performed by JPT Peptide Technologies (Berlin, Germany).

\subsection{Statistics}

Frequencies (most probable numbers (MPN)) of cells responding in the ELISpot assay, and the corresponding $95 \%$ confidence intervals, were calculated by intercept-free linear regression analysis from the linear portions of regression lines based on spot counts from triplicate assay cultures for each of the graded cell numbers seeded [65]. Differences between multiple groups were evaluated using one-way ANOVA with Bonferroni's posthoc test and were considered as being significant at significance levels of $p<0.05\left(^{*}\right)$, $p<0.01\left(^{* *}\right)$ or $p<0.001\left(^{* * *}\right)$. All calculations were performed using Graph Pad Prism 6.04, (Graph Pad Software, San Diego, CA, USA).

\section{Results and Discussion}

\subsection{Reduced Frequency of Viral Epitope-Specific Functional IFN $\gamma^{+} C D 8^{+} T$ Cells in the EVC of} Latently Infected Lungs

To isolate leucocytes, including $\mathrm{CD}^{+} \mathrm{T}$ cells, from the compartments (defined in Figure 1) of latently infected lungs, a gentle bronchoalveolar lavage was performed as a first step to retrieve cells that are only loosely attached to parenchymal epithelial cells of the alveoli, defining the EVC. Blood leucocytes were isolated to represent the IVC, and, as the last step, perfusion-resistant leucocytes were retrieved by enzymatic digestion of lung tissue. This yields intravascular leucocytes that are more firmly attached to EC lining the lung capillaries, cells in the process of transmigration, and extravascular cells localizing to the connective tissue of the interstitium. As these three localizations cannot easily be separated experimentally, they are here collectively referred to as TMC.

Cells with the functional capacity to produce IFN $\gamma$ upon stimulation with presented viral antigenic peptides were quantitated in an ELISpot assay and were normalized to the proportion of $\mathrm{CD} 45^{+} \mathrm{CD} 8{ }^{+} \mathrm{T}$ cells determined in parallel by cytofluorometric analysis of the respective leucocyte suspensions (Figure 2).

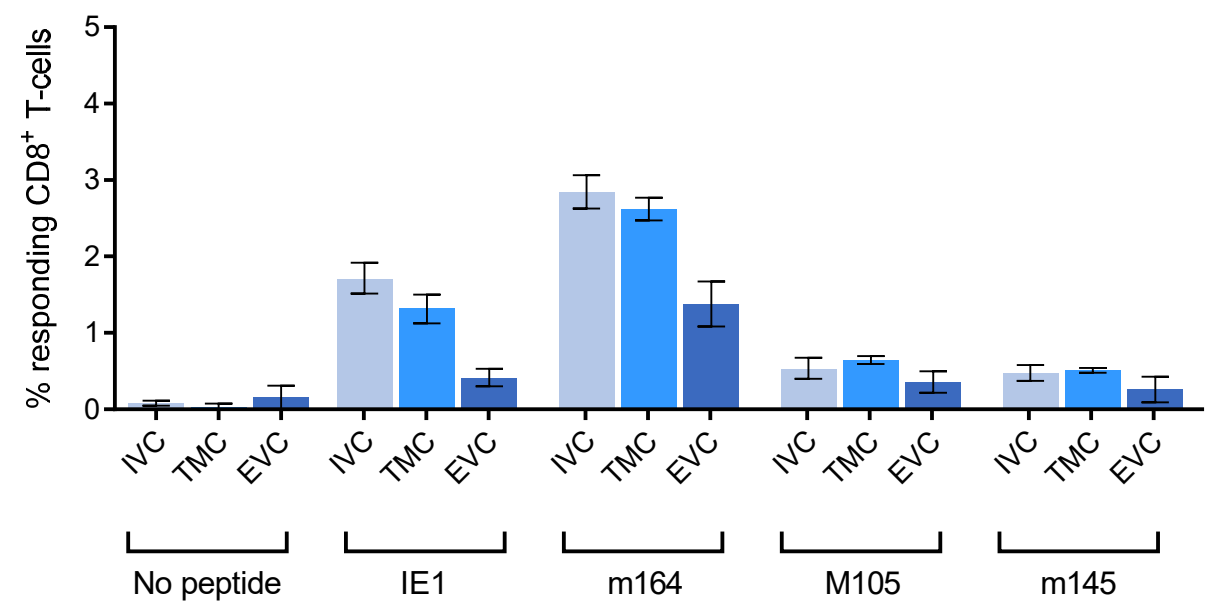

Figure 2. Diminished frequency of epitope-specific functional IFN $\gamma^{+} \mathrm{CD} 8^{+} \mathrm{T}$ cells in the EVC. The analysis was performed 8 months after HCT and infection with mCMV. Bars represent frequencies of $\mathrm{CD}^{+} \mathrm{T}$ cells specific for the viral antigenic peptides indicated and localizing to the lung compartments indicated (defined in Figure 1). Error bars represent the 95\% confidence intervals (CI) determined by intercept-free linear regression analysis of the ELISpot data. Differences are significant when $95 \%$ CI do not overlap. 
The experiment was originally undertaken with the expectation that viral epitopespecific $\mathrm{CD}^{+} \mathrm{T}$ cells floating in the lung capillaries would selectively bind to latently infected EC of the capillary wall and thus would be found enriched in the TMC. At a glance, this was not the case for any of the four viral epitopes tested, although the genes coding for the established immunodominant and MI-driving antigenic peptides IE1 and $\mathrm{m} 164$ [62], and also the gene coding for M105, are stochastically expressed in lung EC during latency [53]. Rather, within the 95\% confidence intervals, frequencies were comparable in IVC and TMC. In contrast, frequencies were significantly reduced in the EVC for all four viral epitopes tested. Although this shows that functional IFN $\gamma^{+} \mathrm{CD}^{+} \mathrm{T}$ cells can, in principle, localize to the lung epithelium also during latent infection of the lungs, their frequency is lower at this site than it is in IVC and TMC.

\subsection{Localization of Viral Epitope-Specific CD8 ${ }^{+}$T-Cell Activation Subsets in Latently Infected Lungs}

MI during viral latency is based on an expansion primarily of CD8 ${ }^{+}$iTEM that are characterized by the cell surface marker phenotype $\mathrm{KLRG}^{+} \mathrm{CD}^{2} \mathrm{~L}^{-}$. For localizing iTEM in latently infected lungs, we therefore determined the frequencies of iTEM in the three compartments in comparison to the frequencies of $\mathrm{KLRG1}^{-} \mathrm{CD}^{-} \mathrm{L}^{-}$cTEM and $\mathrm{KLRG1}^{-} \mathrm{CD} 62 \mathrm{~L}^{+}$ TCM (cytofluorometric data: Figure 3 and Figure S1, summary of results: Figure 4). It should be noted that here we did not further subdivide iTEM by expression of CD127 (IL7-R) because KLRG1 ${ }^{+} \mathrm{CD} 127^{+}$double-positive effector cells (DPEC) do not contribute to $\mathrm{MI}$ in latently infected lungs [53].

Regarding absolute cell numbers, the yield of $\mathrm{CD} 8^{+} \mathrm{T}$ cells is generally low in the EVC, which is what one would expect for a nonlymphoid site during a nonacute infection. In particular, in the IVC, we noted an unexpected additional subpopulation of $\mathrm{CD} 45^{+} \mathrm{CD} 8^{+} \mathrm{T}$ cells with the cell surface marker phenotype $\mathrm{KLRG}^{+} \mathrm{CD}^{2} \mathrm{~L}^{+}$(Figure 3). Interestingly, this population was present also among viral epitope-specific $\mathrm{CD}^{2} 5^{+} \mathrm{CD} 8^{+} \mathrm{IE}-\mathrm{TCR}^{+}$cells. At the moment, we can only speculate that these cells may represent iTEM in a state of transition to memory cells, a state during which KLRG1 is not yet downregulated but CD62L already reacquired. We did here not pursue this subpopulation and its potential function but found its existence worth noting for future work by ourselves or by other investigators.

A compilation of all our cytofluorometric analyses of viral epitope-specific CD8 ${ }^{+} \mathrm{T}$-cell subset localization in latently infected lungs (Figure 4) revealed a picture for the iTEM that strikingly parallels the lung compartment distribution shown in Figure 2 for viral epitope-specific functional IFN $\gamma^{+} \mathrm{CD} 8^{+} \mathrm{T}$ cells, namely, a deprivation in the EVC compared to IVC and TMC. In contrast, cTEM were enriched in the EVC compared to IVC and TMC. This mirror image in the distribution suggests that iTEM lose KLRG1 and convert to cTEM after they have reached the lung epithelium. This interpretation is supported by the known fact that maintenance of KLRG1 requires continuous or at least frequent restimulation by antigen [52], which is not the case in the lung parenchyma because pneumocytes are not latently infected and thus do not present antigen during latency.

A puzzling question is why we did not find an enrichment of viral epitope-specific cells in the TMC, although latently infected EC in the capillary walls sporadically express epitope-encoding viral genes [53]. One possibility is that we observe a steady-state level in which influx and efflux into and out of this compartment are in balance. Our data cannot decide between the competing hypotheses of MI taking place at the latently infected lung endothelium [58] or in lymphoid tissues, specifically in lung-draining lymph nodes [57]. Cells recognizing antigens presented by latently infected EC of the endothelium need to detach for cell division. So, epitope-specific $\mathrm{CD} 8^{+} \mathrm{T}$ cells stimulated at the endothelium of the pulmonary capillary bed might detach and migrate to the lung-draining lymph nodes for proliferation before they return as iTEM to the lungs for immune surveillance [66].

Finally, as one would have expected for an extralymphoid site, the frequency of viral epitope-specific TCM was low in all three compartments, and TCM were actually undetectable in the EVC. 
IVC
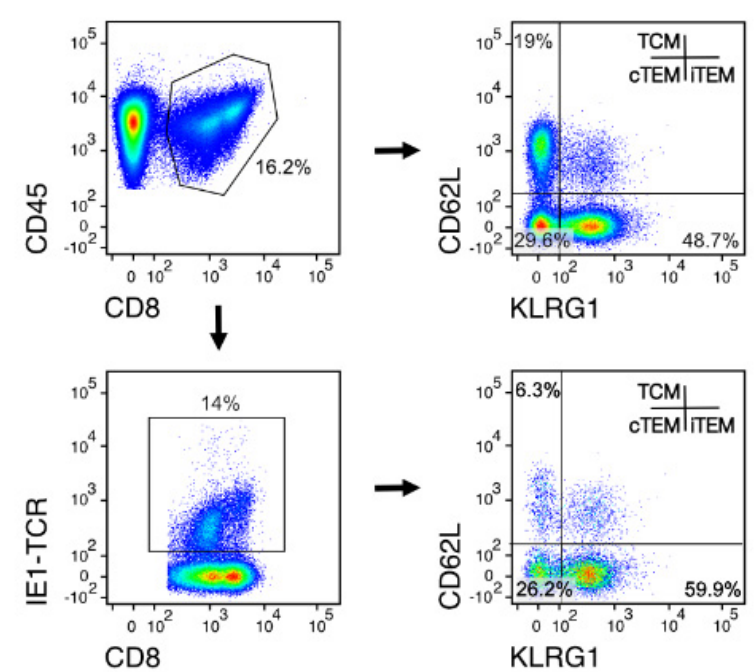

EVC
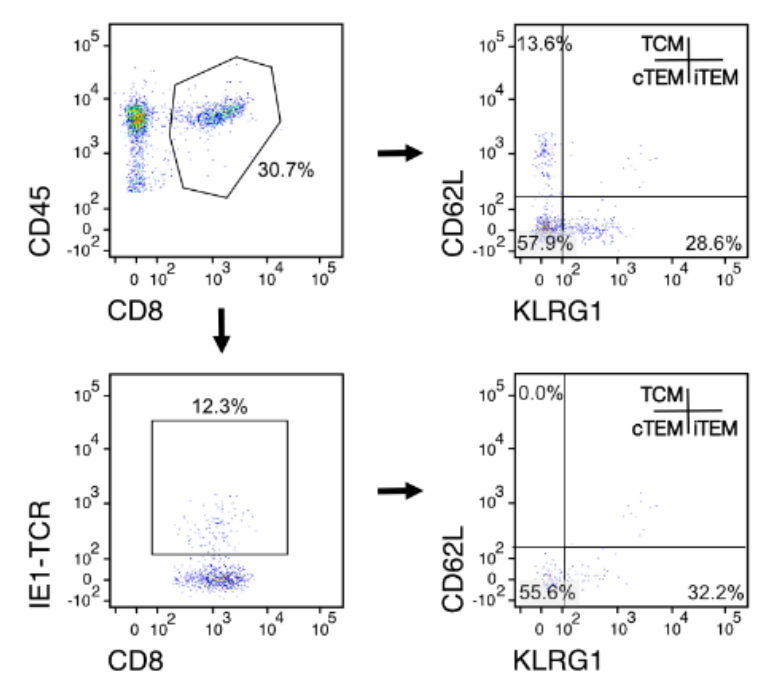

\section{TMC}
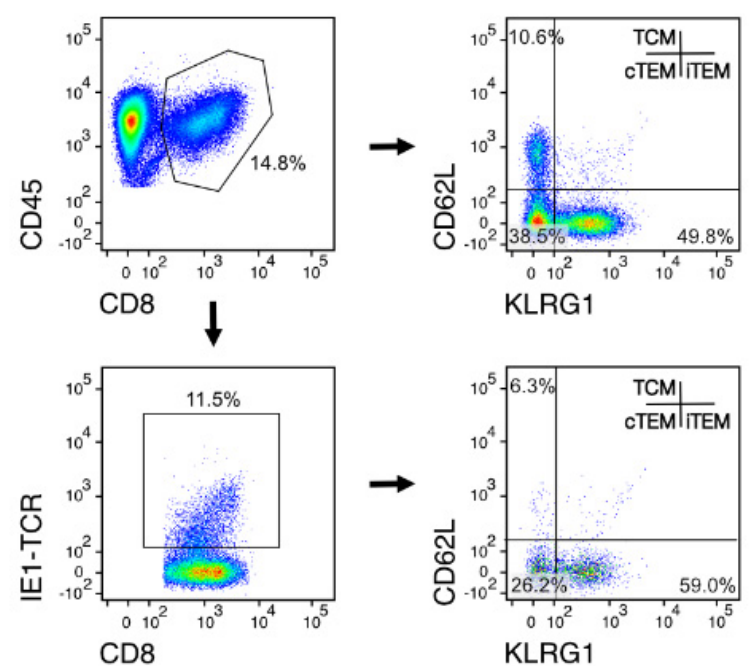

Figure 3. Cytofluorometric relative quantitation of total and IE1 epitope-specific subsets of $\mathrm{CD}^{+} \mathrm{T}$ cells in lung compartments. Data correspond to the functional data of the experiment shown in Figure 2. Shown are representative examples illustrating the gating strategy and the definition of activation subsets iTEM, cTEM, and TCM by combination of the cell surface markers KLRG1 and CD62L among pregated total CD45 ${ }^{+} \mathrm{CD} 8^{+} \mathrm{T}$ cells or among IE1 epitope-specific CD45 ${ }^{+} \mathrm{CD} 8^{+} \mathrm{T}$ cells that were defined by expression of T-cell receptors specific for IE1 peptide presented by the MHC class-I molecule $\mathrm{L}^{\mathrm{d}}$. The complete gating strategy, including a gate set on $\mathrm{CD}_{4} 5^{+}$cells to distinguish between hematopoietic lineage-derived leucocytes and tissue cells, is shown in Figure S1 for a representative example of the TMC, in which CD45 ${ }^{-}$tissue cells released by the enzymatic tissue digest could be technically interfering contaminants. 

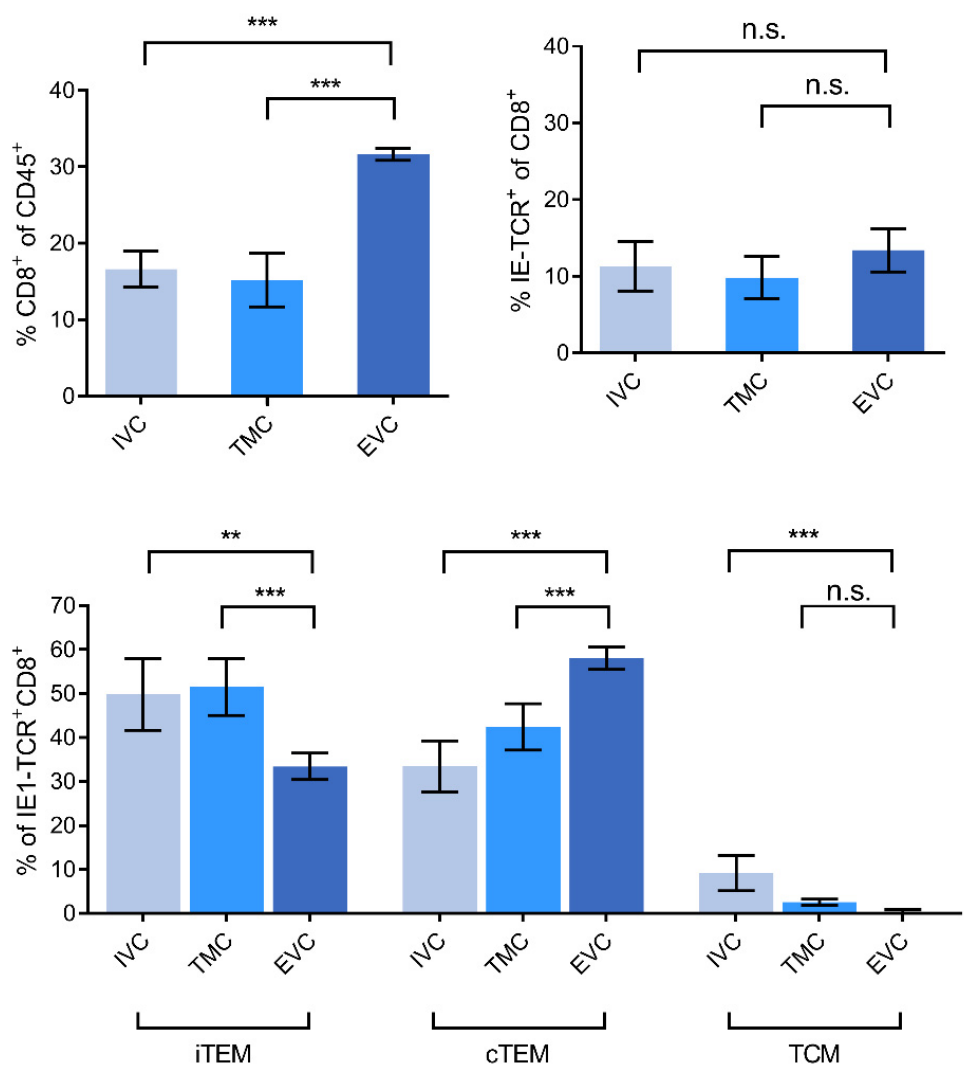

Figure 4. Summary of cytofluorometric localization data. Bars represent mean values, and error bars represent standard deviations for 12 pools of the leucocyte yield of 3 mice per pool $(n=12)$ in the case of IVC and TMC, and for 4 pools of the leucocyte yield from 9 mice per pool $(n=4)$ in the case of the EVC. Significance levels are shown for groups of most interest. $\left({ }^{* *}\right) \mathrm{p}<0.01 .\left({ }^{* * *}\right) p<0.001$. (n.s.) not significant, $p>0.05$.

\subsection{Acute Airway Challenge Infection Recruits $C D 8^{+} T$ Cells into the TMC and EVC in an Epitope-Specific Manner}

Data so far have shown that functional IFN $\gamma^{+} \mathrm{CD} 8^{+} \mathrm{T}$ cells (Figure 2) and iTEM (Figure 4) are both deprived in the EVC in latently infected mice. We have explained this by conversion of KLRG1 ${ }^{+}$iTEM into KLRG1 ${ }^{-}$cTEM due to a lack of antigen presentation by lung epithelial cells, which are not cellular sites of latent mCMV infection. If this explanation holds true, it must be postulated that acute infection of lung parenchyma in latently infected mice leads to antigen presentation that restimulates CTEM in the EVC and converts them into iTEM, and infection likely also recruits cells from the IVC into the TMC and further into the EVC. As an approach, we used airway superinfection of latently infected mice, a model that has a clinical correlate since humans latently infected with hCMV can be exposed to infectious virions via the airways upon intimate contact with acutely infected children who shed virus produced in salivary gland epithelial cells into the saliva. To be sure that the virus reaches the alveolar epithelium, we chose intratracheal infection, which also activates migratory $\mathrm{CD} 11 \mathrm{~b}^{+}$as well as $\mathrm{CD} 103^{+}$dendritic cells [63]. Acute superinfection with a virus mutant in which MI-driving, immunodominant epitopes (IDE) IE1 and m164 are functionally deleted by X9A point mutations of the respective C-terminal amino acid residues (mCMV- $\Delta \mathrm{IDE}$ ) cannot restimulate $\mathrm{CD} 8^{+} \mathrm{T}$ cells specific for these epitopes in mice latently infected with wild-type virus (mCMV-WT.BAC) encoding IE1 and m164. In contrast, restimulation of cells specific for IE1 and m164 should occur after acute superinfection with $\mathrm{mCMV}-\triangle \mathrm{IDE} \_$rev, in which mutations $\mathrm{X} 9 \mathrm{~A}$ are back-mutated to A9X to restore antigenicity and immunogenicity [61] (Figure 5). 

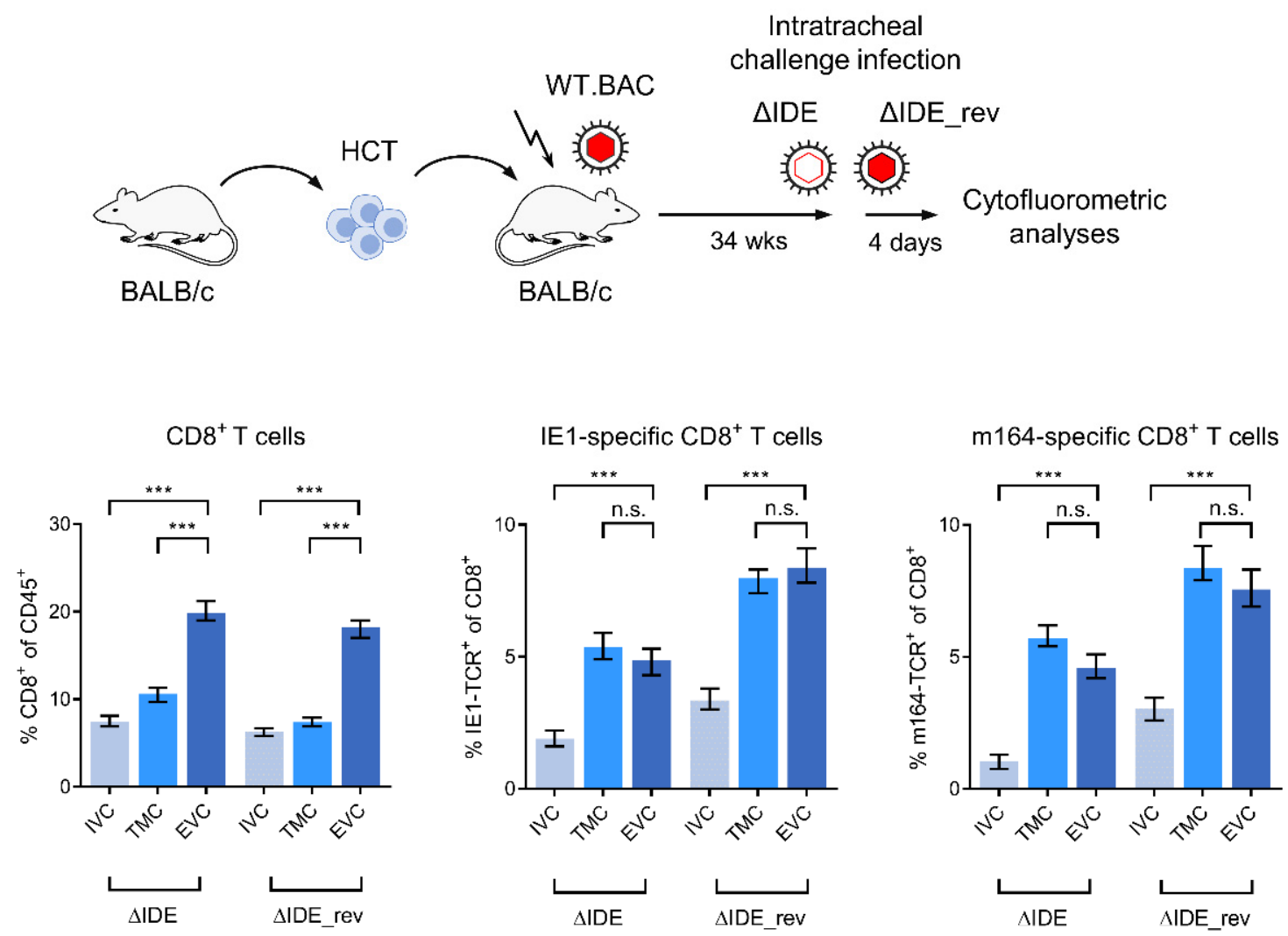

Figure 5. Acute airway superinfection recruits CD8 ${ }^{+} \mathrm{T}$ cells into TMC and EVC in an epitope-unspecific and an epitopespecific manner. (Top) Scheme of the experimental protocol used to test for viral epitope-specific recruitment by airway challenge infection. (Bottom) Summary of relative cytofluorometric quantitations. Bars represent median values, and error bars represent the range of 4 pools from 4 mice each $(n=4)$ in the case of IVC and TMC, and, owing to low cell yield, of 2 pools from 8 mice each $(n=2)$ in the case of the EVC. See the body of the text for further explanation. Significance levels are shown for groups of most interest. $\left.{ }^{* * *}\right) p<0.001$. (n.s.) not significant, $p>0.05$.

Compared to the compartment distribution of viral epitope-specific CD8 ${ }^{+} \mathrm{T}$ cells in latently infected lungs prior to an acute airway superinfection (Figure 4), which is characterized by similar frequencies in IVC and TMC and a deprivation in the EVC, the pattern is shifted to a deprivation in the IVC and similar frequencies in TMC and EVC. Notably, the recruitment to TMC and EVC has an epitope-unspecific component seen for IE1-specific and for $\mathrm{m} 164$-specific $\mathrm{CD} 8^{+} \mathrm{T}$ cells after airway superinfection with $\mathrm{mCMV}$ $\triangle \mathrm{IDE}$ not expressing these two epitopes. A likely explanation is a chemokine-mediated recruitment of $\mathrm{CD}^{+} \mathrm{T}$ cells to the site of infection, as we have shown previously for mast cell-derived chemokine CCL5 in a model of acute mCMV infection of the lungs [67]. Recruited $\mathrm{CD} 8^{+} \mathrm{T}$ cells in this acute infection model localized histologically to TMC and EVC and controlled the infection of the alveolar epithelium. Added to this chemokinemediated recruitment is an epitope-dependent recruitment and clonal expansion, as it is revealed by further increased frequencies of IE1-specific and m164-specific CD ${ }^{+} \mathrm{T}$ cells in TMC and EVC upon airway superinfection with mCMV- $\triangle$ IDE_rev expressing these two epitopes (Figure 5).

\section{Conclusions}

Our data reveal a caveat about the definition of "tissue resident" $\mathrm{CD} 8^{+} \mathrm{T}$ cells. In particular, in the case of the lungs, in which a widely ramified capillary bed serves for gas exchange, it is important to distinguish between cells floating in the capillaries (IVC), cells adhering to the capillary endothelium, or being in the process of transmigration (TMC), and cells that localize to the lung parenchyma, the alveolar epithelium (EVC). We show here that $\mathrm{KLRG}^{+} \mathrm{CD} 62 \mathrm{~L}^{-}$iTEM, which account for the phenomenon of "memory inflation" 
(MI) during latent infection of the lungs, primarily localize to the IVC and TMC, where they receive stimulation by latently infected EC that present antigenic peptides during sporadic episodes of viral gene expression. Upon localization to the alveolar epithelium, which is not latently infected, iTEM become deprived of stimulation by antigen, lose the expression of KLRG1, and convert to KLRG1- ${ }^{-}$D62 $\mathrm{L}^{-}$cTEM. In line with this scenario, provision of antigens in the alveolar epithelium by acute airway superinfection recruits epitope-specific CD8 ${ }^{+} \mathrm{T}$ cells from the IVC to the TMC and also to the EVC.

Supplementary Materials: The following are available online at https:/ /www.mdpi.com/article/10 .3390/life11090918/s1, Figure S1: Representative example of the complete gating strategy for cells in the TMC to exclude contaminating CD45- lung tissue cells from the analysis.

Author Contributions: Conceptualization, M.J.R. and N.A.W.L.; validation, N.A.W.L.; formal analysis, F.B., D.L. and N.A.W.L.; investigation, F.B., D.L. and N.A.W.L.; writing-original draft preparation, M.J.R.; writing — review and editing, N.A.W.L.; visualization, F.B. and N.A.W.L.; supervision, N.A.W.L.; project administration, N.A.W.L.; funding acquisition, M.J.R. and N.A.W.L. All authors have read and agreed to the published version of the manuscript. All authors contributed to manuscript revision, read and approved the submitted version.

Funding: Research from the authors was funded by the Deutsche Forschungsgemeinschaft, Collaborative Research Center (CRC) 1292: individual project TP11 'Viral evasion of innate and adaptive immune cells and inbetweeners' (M.J.R. and N.A.W.L.), and TP15 'Mechanisms controlling Th17 and regulatory $\mathrm{T}$ cells in the anti-Leishmania response' (D.L.). The research was further supported by the Koeln Fortune Program/Faculty of Medicine, University of Cologne (D.L.).

Institutional Review Board Statement: Animal experiments were approved by the ethics committee of the 'Landesuntersuchungsamt Rheinland-Pfalz' according to German federal law §8 Abs. 1 TierSchG (animal protection law), permission numbers 177-07/G14-1-015 and 177-07/G10-1-052.

Informed Consent Statement: Not applicable

Data Availability Statement: The data presented in this study are available on request from the corresponding author.

Acknowledgments: We thank Ingrid Aschmann for her contributions in the early stage of the project and Kirsten Freitag for expert technical assistance.

Conflicts of Interest: The authors declare no conflict of interest.

\section{References}

1. Davison, A.J.; Holton, M.; Dolan, A.; Dargan, D.J.; Gatherer, D.; Hayward, G.S. Comparative genomics of primate cytomegaloviruses. In Cytomegaloviruses: From Molecular Pathogenesis to Intervention; Reddehase, M.J., Ed.; Caister Academic Press: Norfolk, UK, 2013; Volume I, pp. 1-22.

2. Britt, W. Manifestations of human cytomegalovirus infection: Proposed mechanisms of acute and chronic disease. Curr. Top. Microbiol. Immunol. 2008, 325, 417-470. [CrossRef]

3. Ho, M. The history of cytomegalovirus and its diseases. Med. Microbiol. Immunol. 2007, 197, 65-73. [CrossRef]

4. Boppana, S.B.; Britt, W.J. Synopsis of clinical aspects of human cytomegalovirus disease. In Cytomegaloviruses: From Molecular Pathogenesis to Intervention; Reddehase, M.J., Ed.; Caister Academic Press: Norfolk, UK, 2013; Volume 1, pp. 1-25.

5. Cannon, M.J.; Grosse, S.D.; Fowler, K.B. The epidemiology and public health impact of congenital cytomegalovirus infection. In Cytomegaloviruses: From Molecular Pathogenesis to Intervention; Reddehase, M.J., Ed.; Caister Academic Press: Norfolk, UK, 2013; Volume 2, pp. 26-48.

6. Grosse, S.D.; Ortega-Sanchez, I.R.; Bialek, S.R.; Dollard, S.C. The economic impact of congenital CMV infection: Methods and estimates. In Cytomegaloviruses: From Molecular Pathogenesis to Intervention; Reddehase, M.J., Ed.; Caister Academic Press: Norfolk, UK, 2013; Volume 2, pp. 49-54.

7. Plotkin, S.A.; Plachter, B. Cytomegalovirus vaccine: On the way to the future? In Cytomegaloviruses: From Molecular Pathogenesis to Intervention; Reddehase, M.J., Ed.; Caister Academic Press: Norfolk, UK, 2013; Volume 2, pp. 424-449.

8. Plotkin, S. The history of vaccination against cytomegalovirus. Med. Microbiol. Immunol. 2015, 204, 247-254. [CrossRef]

9. Gogesch, P.; Penner, I.; Krauter, S.; Büscher, N.; Grode, L.; Aydin, I.; Plachter, B. Production strategies for pentamer-positive subviral dense bodies as a safe human cytomegalovirus vaccine. Vaccines 2019, 7, 104. [CrossRef]

10. Plotkin, S.A.; Wang, D.; Oualim, A.; Diamond, D.J.; Kotton, C.N.; Mossman, S.; Carfi, A.; Anderson, D.; Dormitzer, P.R. The status of vaccine development against the human cytomegalovirus. J. Infect. Dis. 2020, 221, S113-S122. [CrossRef] [PubMed] 
11. Pereira, L.; Maidji, E.; McDonagh, S.; Tabata, T. Routes of human CMV transmission and infection at the uterine-placental interface. In Cytomegaloviruses: From Molecular Pathogenesis to Intervention; Reddehase, M.J., Ed.; Caister Academic Press: Norfolk, UK, 2013; Volume 2, pp. 74-87.

12. Tabata, T.; Petitt, M.; Fang-Hoover, J.; Pereira, L. Survey of cellular immune responses to human cytomegalovirus infection in the microenvironment of the uterine-placental interface. Med. Microbiol. Immunol. 2019, 208, 475-485. [CrossRef] [PubMed]

13. Adler, S.P.; Nigro, G. Clinical cytomegalovirus research: Congenital infection. In Cytomegaloviruses: From Molecular Pathogenesis to Intervention; Reddehase, M.J., Ed.; Caister Academic Press: Norfolk, UK, 2013; Volume 2, pp. 55-73.

14. Roizman, B.; Sears, A.E. An inquiry into the mechanisms of herpes simplex virus latency. Annu. Rev. Microbiol. 1987, 41, 543-571. [CrossRef] [PubMed]

15. Reeves, M.; Sinclair, J. Epigenetic regulation of human cytomegalovirus gene expression: Impact on latency and reactivation. In Cytomegaloviruses: From Molecular Pathogenesis to Intervention; Reddehase, M.J., Ed.; Caister Academic Press: Norfolk, UK, 2013; Volume 1, pp. 330-346.

16. Collins-McMillen, D.; Goodrum, F.D. The loss of binary: Pushing the herpesvirus latency paradigm. Curr. Clin. Microbiol. Rep. 2017, 4, 124-131. [CrossRef] [PubMed]

17. Shnayder, M.; Nachshon, A.; Krishna, B.; Poole, E.; Boshkov, A.; Binyamin, A.; Maza, I.; Sinclair, J.; Schwartz, M.; Stern-Ginossar, N. Defining the transcriptional landscape during cytomegalovirus latency with single-cell RNA sequencing. mBio 2018, 9, e00013-18. [CrossRef]

18. Schwartz, M.; Stern-Ginossar, N. The transcriptome of latent human cytomegalovirus. J. Virol. 2019, 93, e00047-19. [CrossRef]

19. Poole, E.; Neves, T.C.; Oliveira, M.T.; Sinclair, J.; Da Silva, M.C.C. Human cytomegalovirus interleukin 10 homologs: Facing the immune system. Front. Cell. Infect. Microbiol. 2020, 10, 245. [CrossRef] [PubMed]

20. Poole, E.; Sinclair, J. Understanding HCMV latency using unbiased proteomic analyses. Pathogens 2020, 9, 590. [CrossRef] [PubMed]

21. Emery, V.C.; Milne, R.S.B.; Griffiths, P.D. Clinical cytomegalovirus research: Liver and kidney transplantation. In Cytomegaloviruses: From Molecular Pathogenesis to Intervention; Reddehase, M.J., Ed.; Caister Academic Press: Norfolk, UK, 2013; Volume 2, pp. 301-311.

22. Seo, S.; Boeckh, M. Clinical cytomegalovirus research: Hematopoietic cell transplantation. In Cytomegaloviruses: From Molecular Pathogenesis to Intervention; Reddehase, M.J., Ed.; Caister Academic Press: Norfolk, UK, 2013; Volume 2, pp. $337-353$.

23. Taylor-Wiedeman, J.; Sissons, J.G.P.; Borysiewicz, L.K.; Sinclair, J.H. Monocytes are a major site of persistence of human cytomegalovirus in peripheral blood mononuclear cells. J. Gen. Virol. 1991, 72, 2059-2064. [CrossRef] [PubMed]

24. Maciejewski, J.P.; Bruening, E.E.; Donahue, R.E.; Mocarski, E.S.; Young, N.S.; St Jeor, S.C. Infection of hematopoietic progenitor cells by human cytomegalovirus. Blood 1992, 80, 170-178. [CrossRef] [PubMed]

25. Kondo, K.; Kaneshima, H.; Mocarski, E.S. Human cytomegalovirus latent infection of granulocyte-macrophage progenitors. Proc. Natl. Acad. Sci. USA 1994, 91, 11879-11883. [CrossRef] [PubMed]

26. Mendelson, M.; Monard, S.; Sissons, P.; Sinclair, J. Detection of endogenous human cytomegalovirus in CD34+ bone marrow progenitors. J. Gen. Virol. 1996, 77, 3099-3102. [CrossRef]

27. Söderberg-Nauclér, C.; Fish, K.; Nelson, J.A. Reactivation of latent human cytomegalovirus by allogeneic stimulation of blood cells from healthy donors. Cell 1997, 91, 119-126. [CrossRef]

28. Hahn, G.; Jores, R.; Mocarski, E.S. Cytomegalovirus remains latent in a common precursor of dendritic and myeloid cells. Proc. Natl. Acad. Sci. USA 1998, 95, 3937-3942. [CrossRef] [PubMed]

29. Reddehase, M.J.; Lemmermann, N.A.W. Cellular reservoirs of latent cytomegaloviruses. Med. Microbiol. Immunol. 2019, 208, 391-403. [CrossRef]

30. Chemaly, R.F.; Chou, S.; Einsele, H.; Griffiths, P.; Avery, R.; Razonable, R.R.; Mullane, K.M.; Kotton, C.; Lundgren, J.; Komatsu, T.E.; et al. Definitions of resistant and refractory cytomegalovirus infection and disease in transplant recipients for use in clinical trials. Clin. Infect. Dis. 2019, 68, 1420-1426. [CrossRef]

31. Riddell, S.R.; Watanabe, K.; Goodrich, J.; Li, C.; Agha, M.; Greenberg, P. Restoration of viral immunity in immunodeficient humans by the adoptive transfer of T cell clones. Science 1992, 257, 238-241. [CrossRef] [PubMed]

32. Einsele, H.; Roosnek, E.; Rufer, N.; Sinzger, C.; Riegler, S.; Löffler, J.; Grigoleit, U.; Moris, A.; Rammensee, H.-G.; Kanz, L.; et al. Infusion of cytomegalovirus (CMV)-specific T cells for the treatment of CMV infection not responding to antiviral chemotherapy. Blood 2002, 99, 3916-3922. [CrossRef] [PubMed]

33. Odendahl, M.; Grigoleit, G.U.; Bönig, H.; Neuenhahn, M.; Albrecht, J.; Anderl, F.; Germeroth, L.; Schmitz, M.; Bornhäuser, M.; Einsele, H.; et al. Clinical-scale isolation of 'minimally manipulated' cytomegalovirus-specific donor lymphocytes for the treatment of refractory cytomegalovirus disease. Cytotherapy 2014, 16, 1245-1256. [CrossRef] [PubMed]

34. Kaeuferle, T.; Krauss, R.; Blaeschke, F.; Willier, S.; Feuchtinger, T. Strategies of adoptive T-cell transfer to treat refractory viral infections post allogeneic stem cell transplantation. J. Hematol. Oncol. 2019, 12, 13. [CrossRef]

35. Winston, D.J.; Ho, W.G.; Champlin, R.E. Cytomegalovirus infections after allogeneic bone marrow transplantation. Clin. Infect. Dis. 1990, 12, S776-S792. [CrossRef]

36. Quabeck, K. The lung as a critical organ in marrow transplantation. Bone Marrow Transplant. 1994, 14, S19-S28.

37. Riddell, S.R. Pathogenesis of cytomegalovirus pneumonia in immunocompromised hosts. Semin. Respir. Infect. 1995, 10, 199-208.

38. Reddehase, M.J. Mutual interference between cytomegalovirus and reconstitution of protective immunity after hematopoietic cell transplantation. Front. Immunol. 2016, 7, 294. [CrossRef] 
39. Reddehase, M.J.; Lemmermann, N.A.W. Mouse model of cytomegalovirus disease and immunotherapy in the immunocompromised host: Predictions for medical translation that survived the "test of time". Viruses 2018, 10, 693. [CrossRef]

40. Reddehase, M.J.; Holtappels, R.; Lemmermann, N.A.W. Consequence of histoincompatibility beyond GvH-reaction in cytomegalovirus disease associated with allogeneic hematopoietic cell transplantation: Change of paradigm. Viruses 2021, 13, 1530. [CrossRef] [PubMed]

41. Podlech, J.; Holtappels, R.; Pahl-Seibert, M.-F.; Steffens, H.-P.; Reddehase, M.J. Murine model of interstitial cytomegalovirus pneumonia in syngeneic bone marrow transplantation: Persistence of protective pulmonary CD8-T-cell infiltrates after clearance of acute infection. J. Virol. 2000, 74, 7496-7507. [CrossRef]

42. Holtappels, R.; Pahl-Seibert, M.-F.; Thomas, D.; Reddehase, M.J. Enrichment of immediate-early 1 (m123/pp89) peptide-specific CD8 T cells in a pulmonary CD62L lo memory-effector cell pool during latent murine cytomegalovirus infection of the lungs. J. Virol. 2000, 74, 11495-11503. [CrossRef] [PubMed]

43. O'Hara, G.A.; Welten, S.; Klenerman, P.; Arens, R. Memory T cell inflation: Understanding cause and effect. Trends Immunol. 2012, 33, 84-90. [CrossRef] [PubMed]

44. Seckert, C.K.; Griessl, M.; Büttner, J.K.; Scheller, S.; Simon, C.O.; Kropp, K.A.; Renzaho, A.; Kühnapfel, B.; Grzimek, N.K.A.; Reddehase, M.J. Viral latency drives 'memory inflation': A unifying hypothesis linking two hallmarks of cytomegalovirus infection. Med. Microbiol. Immunol. 2012, 201, 551-566. [CrossRef] [PubMed]

45. Klenerman, P.; Oxenius, A. T cell responses to cytomegalovirus. Nat. Rev. Immunol. 2016, 16, 367-377. [CrossRef]

46. Welten, S.; Sandu, I.; Baumann, N.S.; Oxenius, A. Memory CD8 T cell inflation vs tissue-resident memory T cells: Same patrollers, same controllers? Immunol. Rev. 2018, 283, 161-175. [CrossRef]

47. Cicin-Sain, L. Cytomegalovirus memory inflation and immune protection. Med. Microbiol. Immunol. 2019, 208, 339-347. [CrossRef]

48. Welten, S.; Baumann, N.S.; Oxenius, A. Fuel and brake of memory T cell inflation. Med. Microbiol. Immunol. 2019, 208, 329-338. [CrossRef]

49. Snyder, C.M.; Cho, K.S.; Bonnett, E.L.; Van Dommelen, S.; Shellam, G.R.; Hill, A.B. Memory inflation during chronic viral infection is maintained by continuous production of short-lived, functional T cells. Immunity 2008, 29, 650-659. [CrossRef] [PubMed]

50. Holtappels, R.; Freitag, K.; Renzaho, A.; Becker, S.; Lemmermann, N.A.; Reddehase, M.J. Revisiting CD8 T-cell 'memory inflation': New insights with implications for cytomegaloviruses as vaccine vectors. Vaccines 2020, 8, 402. [CrossRef]

51. Baumann, N.S.; Torti, N.; Welten, S.; Barnstorf, I.; Borsa, M.; Pallmer, K.; Oduro, J.D.; Cicin-Sain, L.; Ikuta, K.; Ludewig, B.; et al. Tissue maintenance of CMV-specific inflationary memory T cells by IL-15. PLoS Pathog. 2018, 14, e1006993. [CrossRef]

52. Thimme, R.; Appay, V.; Koschella, M.; Panther, E.; Roth, E.; Hislop, A.D.; Rickinson, A.B.; Rowland-Jones, S.L.; Blum, H.E.; Pircher, H. Increased expression of the NK cell receptor KLRG1 by virus-specific CD8 T cells during persistent antigen stimulation. J. Virol. 2005, 79, 12112-12116. [CrossRef]

53. Griessl, M.; Renzaho, A.; Freitag, K.; Seckert, C.K.; Reddehase, M.J.; Lemmermann, N.A.W. Stochastic episodes of latent cytomegalovirus transcription drive CD8 T-cell "memory inflation" and avoid immune evasion. Front. Immunol. 2021, 12, 668885. [CrossRef] [PubMed]

54. Lemmermann, N.A.W.; Reddehase, M.J. Direct evidence for viral antigen presentation during latent cytomegalovirus infection. Pathogens 2021, 10, 731. [CrossRef] [PubMed]

55. Smith, C.J.; Venturi, V.; Quigley, M.F.; Turula, H.; Gostick, E.; Ladell, K.; Hill, B.J.; Himelfarb, D.; Quinn, K.M.; Greenaway, H.Y.; et al. Stochastic expansions maintain the clonal stability of CD8+T cell populations undergoing memory inflation driven by murine cytomegalovirus. J. Immunol. 2020, 204, 112-121. [CrossRef] [PubMed]

56. Gabel, M.; Baumann, N.S.; Oxenius, A.; Graw, F. Investigating the dynamics of MCMV-specific CD8+ T cell responses in individual hosts. Front. Immunol. 2019, 10, 1358. [CrossRef]

57. Torti, N.; Walton, S.M.; Brocker, T.; Rülicke, T.; Oxenius, A. Non-hematopoietic cells in lymph nodes drive memory CD8 T cell inflation during murine cytomegalovirus infection. PLoS Pathog. 2011, 7, e1002313. [CrossRef] [PubMed]

58. Smith, C.J.; Turula, H.; Snyder, C. Systemic hematogenous maintenance of memory inflation by MCMV infection. PLoS Pathog. 2014, 10, e1004233. [CrossRef]

59. Messerle, M.; Crnkovic, I.; Hammerschmidt, W.; Ziegler, H.; Koszinowski, U.H. Cloning and mutagenesis of a herpesvirus genome as an infectious bacterial artificial chromosome. Proc. Natl. Acad. Sci. USA 1997, 94, 14759-14763. [CrossRef]

60. Wagner, M.; Jonjić, S.; Koszinowski, U.H.; Messerle, M. Systematic excision of vector sequences from the BAC-cloned herpesvirus genome during virus reconstitution. J. Virol. 1999, 73, 7056-7060. [CrossRef]

61. Holtappels, R.; Simon, C.O.; Munks, M.W.; Thomas, D.; Deegen, P.; Kühnapfel, B.; Däubner, T.; Emde, S.F.; Podlech, J.; Grzimek, N.K.A.; et al. Subdominant CD8 T-cell epitopes account for protection against cytomegalovirus independent of immunodomination. J. Virol. 2008, 82, 5781-5796. [CrossRef]

62. Holtappels, R.; Lemmermann, N.; Podlech, J.; Ebert, S.; Reddehase, M.J. Reconstitution of CD8 T cells protective against cytomegalovirus in a mouse model of hematopoietic cell transplantation: Dynamics and inessentiality of epitope immunodominance. Front. Immunol. 2016, 7, 232. [CrossRef] [PubMed]

63. Reuter, S.; Lemmermann, N.A.W.; Maxeiner, J.; Podlech, J.; Beckert, H.; Freitag, K.; Teschner, D.; Ries, F.; Taube, C.; Buhl, R.; et al. Coincident airway exposure to low-potency allergen and cytomegalovirus sensitizes for allergic airway disease by viral activation of migratory dendritic cells. PLoS Pathog. 2019, 15, e1007595. [CrossRef] [PubMed] 
64. Maxeiner, J.H.; Karwot, R.; Hausding, M.; Sauer, K.A.; Scholtes, P.; Finotto, S. A method to enable the investigation of murine bronchial immune cells, their cytokines and mediators. Nat. Protoc. 2007, 2, 105-112. [CrossRef]

65. Böhm, V.; Simon, C.O.; Podlech, J.; Seckert, C.K.; Gendig, D.; Deegen, P.; Gillert-Marien, D.; Lemmermann, N.; Holtappels, R.; Reddehase, M.J. The immune evasion paradox: Immunoevasins of murine cytomegalovirus enhance priming of CD8 T cells by preventing negative feedback regulation. J. Virol. 2008, 82, 11637-11650. [CrossRef] [PubMed]

66. Simon, C.O.; Holtappels, R.; Tervo, H.-M.; Böhm, V.; Däubner, T.; Oehrlein-Karpi, S.A.; Kühnapfel, B.; Renzaho, A.; Strand, D.; Podlech, J.; et al. CD8 T cells control cytomegalovirus latency by epitope-specific sensing of transcriptional reactivation. J. Virol. 2006, 80, 10436-10456. [CrossRef]

67. Ebert, S.; Becker, M.; Lemmermann, N.; Büttner, J.K.; Michel, A.; Taube, C.; Podlech, J.; Böhm, V.; Freitag, K.; Thomas, D.; et al. Mast cells expedite control of pulmonary murine cytomegalovirus infection by enhancing the recruitment of protective CD8 T cells to the lungs. PLoS Pathog. 2014, 10, e1004100. [CrossRef] [PubMed] 